\title{
Dividend Policy and Ownership Structure: An Applied Study on Industrial Companies in Amman Stock Exchange
}

\author{
Mahmoud Al-Nawaiseh \\ Faculty of business and finance \\ The University of Jordan \\ E-mail: nawaisehm@yahoo.com
}

Received: Dec. 20, 2012

Accepted: January 17, 2013 Published: April 1, 2013

doi:10.5296/jmr.v5i2.2920

URL: http://dx.doi.org/10.5296/jmr.v5i2.2920

\begin{abstract}
This study aims to determine whether ownership structure is linked to the dividend policy on industrial companies are listed in ASE.

The study sample consisted of sixty two industrial firms listed in ASE from (2000-2006).In order to achieve the objective of the study, annually dividend and annual report publications of public shareholding firms held by ASE. The Tobit model or censored regression model specification was used to test the study hypotheses for the level of dividends paid. The study was found more than half (55\%) of the firm observation in our sample have zero dividends. Results shows that ownership dispersion as measured by the natural $\log$ of the number of stockholders (STOCK) seems to be not related to dividend policy in Jordan since it was insignificant in both analyses, Tobit and OLS. The fraction held by insiders (INSD), has negative impact on the level of dividends paid. The other ownership, family is negatively but not significantly, and institution is positively and significant influence on the dividend policy, the multiple ownership is negative and insignificant, the finally variable for ownership is foreigner positive and insignificant.
\end{abstract}

Keywords: Dividend Policy, Ownership Structure, Industry Companies, Jordan 


\section{Introduction}

The main objective of this study is to investigate the relationship between ownership structure and dividend policy of Jordanian industrial firms which are listed in ASE.

Dividend payout has been an issue in financial literature. (Jensen \& Meckling,1976) argue that information asymmetry between 'insiders' and 'outsider' may relate to agency cost.

On of the mechanisms they suggested to reduce outsiders' expropriation is to reduce free cash flow available to manager through high payout by the firm in form of dividend and repurchases this dividend payment lessen his ability to over-invest and gain benefits not shared with other Shareholders (Jensen, 1986). Moreover, high dividend levels increase the need to turn to the capital market frequently to finance future investment, with the consequence that the power of external investors increases and in turn facilitate the monitoring of firms by external capital markets (Esterbook, 1984).

It is also important to note that the extent to which the firm's dividend policy is effective in reducing the expected agency costs may also depend on its ownership and control structure.Recent researches emphasize the potential conflicts of interest between controlling shareholders and minority shareholders, ( Shleifer \& Vishny, 1997) argue that when large owners gain nearly full control of the corporation, they prefer to generate private benefits of control that are not shared by minority shareholders (Faccio, 2001; Holderness, 2003). That is firms with large controlling shareholders may exhibit a different type of agency conflict, namely the expropriation of minority shareholders by majority shareholders.

On the other, hand in the presence of large share holders, managerial discretion can be curbed to some extent and agency costs between managers and shareholders are reduced because large shareholders have the ability and incentives to monitor and discipline management (Stiglitz, 1985; Shleifer \& Vishny, 1986). This would in turn imply a lesser role for corporate payout policy to address agency problems between corporate insiders and outside shareholders.

In spite of few studies arguing that the factors effecting dividend policy in Jordanian firms.this study attempts to provide more insight into the literature by providing an empirical analysis on the relationship between corporate payout policy and ownership structures. More specifically, it will empirically investigate the relationship of ownership and control structure of firms on their dividend payments by using a sample of Jordanian firms listed on the Amman Stock Exchange.

\section{Problem Statement}

Dividend policies are one of the most issues in modern corporate finance.There are many researchers who have provided insights, theoretical as well as empirical, into the dividend policy puzzle. However, the issue as to why firms pay dividends is as yet unresolved. Several rationales for a corporate dividend policy have been proposed in the literature, but there is no unanimity among researchers. Everyone, however, agrees that the issue is important, as 
dividend payment is one of the most commonly observed phenomena in corporations worldwide.

The issue of dividend policy is important for several reasons:-

First, many of researchers have found that a firm uses dividends as a mechanism for financial signaling to the outsiders regarding the stability and growth prospects of the firm. Second, dividends play an important role in a firm's capital structure. Yet another set of studies have established the relationship between firm dividend and investment decisions. According to the "residual dividend" theory, a firm will pay dividends only if it does not have profitable investment opportunities, i.e., positive net present value projects. Third on the relationship between dividend policy and the value of the firm, different theories have been advanced. The first theory that consider the dividend decision to be irrelevant. According to Miller and Modigliani (M\& M), under the a perfect market situation, the dividend policy of a firm is irrelevant, as does not affect the value of the firm. The second theory that considers the dividend decision to be relevant factor influencing the value of the firm, (Walter \& James, 1963).

In Jordan area there many studies were carried out to investigate the determinants of dividend policy and stability dividend for companies which are listed in ASE. This study employed the ownership frame work to investigate the relationship between ownership structure and dividend policy, because since is important to take dividend decision by financial managers, and on the other hand, it is important for investors to understand the firm dividend policy. Through the relationship between ownership structure and dividend policy specifically, the vital role of the dividend policy is to attract more capitals and foreign investors and protect the right of minority shareholders. These reasons stimulated the researcher to investigate this relationship between ownership structure and dividend policy.

This study seeks to answer the following questions:

1- Is there any relationship between dividend policy and ownership structure within the companies which are listed in ASE?

2- What kind of such relationship?

3. Is this relationship a very important factor that affects the dividend policy on industrial firm are listed in ASE?

\section{Importance of the Study}

The relationship between dividend policy and firm's ownership structure examined by several studies within the agency theory framework for different countries.In the case of Jordan it is important to address the relationship separately because of the variety of owners in Jordanian firms, for example (multiple, institution, and family ). These types of owners may have different preferences for dividend payouts (Maruy \& pajuste, 2002).

The importance of this study stems from the role of dividend policy to protect minority shareholders right and attract more foreign capitals and investments. The lack of empirical 
evidence to accept or reject this prediction in emerging markets and particularly in Jordan provides one of the motivation for this study There are many studies carried out to examine the relationship between ownership structure and dividend policy in developed markets such as USA, UK, Germany, and Japan but little work has been carried out to test this relation in emerging markets including the Jordanian markets.

Ultimately, this study, as one of few studies carried out in this area, will contribute to the literature, for the following reasons

1. Amman financial market plays an important role in national economy so this study will aim to explore the relationship between ownership and dividend policy because the corporate ownership structure is very important since it may directly influence corporate decisions, especially about dividend payout.

2. While prior related studies were conducted in well developed markets, this study it will examine this issue in one of the emerging markets.

\section{Study Objectives}

The focus of this study is on the relationship between ownership structures, dividend policy. It will employ an ownership frame work and compare the dividend policy of companies with different ownership structures within the companies which are listed in ASE.

1. This study aims to investigate the relationship between ownership structure and dividend policy of the Jordanian firms that are listed in Amman Stock Exchange from 2000-2006 years.

2. To determine the role of ownership structure toward dividends.

3. To provide a theoretical and empirical research on dividend policy and ownership structure and a number of literature reviews.

4. To provide the Arabic library with scientific material and information dealing with dividend policy, and different ownership structures adapted by companies in one of emergent market.

\section{Literature Review}

There has been a considerable research that discussed corporate finance and identifies the determinants of corporate dividend policy. One branch of this literature has focused on an agency related to payment of dividends.Depending on the idea that monitoring the firm and its management is helpful in reducing agency conflicts, as payment of dividends reduce the discretionary funds available to managers. (Easterbook, 1984),( Meckling, 1976), and (Rozeff, 1982) presented agency cost explanation of changes in dividend payout, while analyzing within dividends can be cut as advice to align managers interests with those of investors. They argue that one way of solving this problem is by increasing the payout ratio to reduce agency costs, as payment of dividend reduce funds available to managers. When the firm increases its dividend payment, assuming it wishes to proceed with planned investment, it is forced to go to the external sources to finance these investments. This induces monitoring by 
potential investors of the firm and its management, thus reducing problem. (Jensen, 1982) documented that in presence of free cash flows; the firms pay dividends or retire their debts to reduce the agency cost of free cash flow.

(Rozeff, 1982) develops the model called the cost minimization model. The model combines the transaction cost that may be controlled by raising the payout ratio. The basic idea of this model resets in that the optimal payout ratio is at the level where the sum of these two types of costs is minimized.

Thus. Rozeff's minimization model is a regression of the firm payout ratio on five variables that proxy for agency and transaction costs.agency costs in the model represented by two variables that proxy for the agency costs. First, the percentage of a firm stock held by insiders, as a proxy for insider ownership and is expected to be negatively related to the target payout ratio. Second, the natural logarithm of the number of common stockholders of a firm is a proxy for ownership dispersion. It is expected to be positively related to the target payout ratio because the greater the dispersion, the more severe is the collective action problem of monitoring. (Jensen, Solberg, \& Zoren, 1992) examined the determinant of cross-sectional differences in insider ownership, debt, and dividend policy. They found that a firm with higher insider ownership chooses lower level of debt and dividend.

(James et al,2000) provided measures of absolute and relative equity agency costs of corporation under different ownership structure. They also examined the determinants of agency costs in a multivariate regression framework. They found that agency costs were higher when an outsider manages the firm. Second result, found that the agency costs vary inversely with the manager's ownership share. Third result, found that the agency costs increase with the number of non manager shareholders. Fourth, found that, to a lesser extent, external monitoring by banks produces a positive externality in the form of lower agency costs.

(Han. L., \& Suk,1999) tested the agency cost based hypothesis, which predicts dividend payout as inversely related to the degree of institutional ownership and the tax based hypothesis, predicting the dividends to be positively related with the institutional ownership. They provide support for the tax based hypotheses, suggesting a dividend clientele for institutions preference for higher dividends.( Gugler, 2003), ( Gugler \& Yurtoglu, 2003) investigated the relationship between dividends, ownership structures and control rights for Austrian and German firms, respectively. (Gugler, 2003) found that the ownership and control structure of the firm is a significant determinant of its dividend payout policy.In particular, state-controlled firms in Austria "smooth" dividends, have large target payout ratio, and are most reluctant to cut dividends, despite of the potential cost involved for shareholders, this is consistent with a managerial /agency cost explanation. In contrast, family -controlled firms peruse a significantly different dividend policy.These firms show no smoothing in dividends, have lower target payout ratio, and are least reluctant to cut dividends. Owner-managers of these firms can reactive to investment opportunities and financing needs, and adjust dividend policy accordingly.Smoothing of dividends is only marginally important in bank and foreign -controlled firms. (Gugler \& Yurtoglu, 2003) found a large shareholder 
of the largest owner reduces the dividends payout ratio, while shareholders by the second larger owner increase the dividend payout ratio.

(Manos, 2002) developed a model to study the factors that are likely to be important in influencing the dividend policy of firms operating in the Indian environment. This model, which is represented by the transaction cost variable, agency cost variable, business group interaction term, and dummy variable. The transaction cost variable is measured by three proxies including GROWTH, RISK, and LIQUID. The agency cost variable is represented by four proxies measuring of equity shares held by various groups of investors are including FOREIGN, INST, DIRS, PUBLIC, respectively. FOREIGN represents the percentage of shares held by foreign shareholders, foreign financial institutions and others. INST measures institutional ownership including the percentage of equity shares held by insurance companies, mutual funds, and Indian financial institutions. DIRS is a proxy for insider ownership and represents the percentage of shares held by the directors of the company. The fourth agency proxies PUBLIC is a measure of ownership dispersion and represents the percentage of shares held by the public at large. (Manos, 2002) found the prediction regarding the impact of the percentage of foreign ownership, FOREIGN, on the payout ratio was undetermined.However, without exception the actual effect is found to be positive indicating that the greater the percentage held by the foreign institutions, the greater need to induce capital market monitoring. This is consistent with the view that, relative to other shareholders, it may be more difficult for overseas investors to monitor the firm and its management. The impact of institutional shareholdings, INST, on the target payout ratio is found to be positive particularly for group- affiliated firms. This is associated with the view that the ability of institutional shareholders, to more effectively monitors the firm, and reduced the need for the dividend device. The impact of PUBLIC, the variable measuring ownership dispersion, on the target payout ratio, is found to be positive. increases in the dispersion of ownership increases the collective action problem of monitoring and thus the need for the dividend induced capital market monitoring.In contrast increases in the percentage of insider ownership, DIRS, which was expected to reduce agency costs and thus to have a negative impact on the target payout ratio, is actually found to be positive and significant, although less so in the case of group affiliated firms.

(Dehaene,\& Ooghe,1998) found that the companies with smallest boards had significant lower payout ratio than the firm with the largest boards, and they discovered that dividend yield of the listed companies in the sample was positively related to the relative importance of inside directors in the board.

(Neo \& Rebello,1996) theorized the relationship between institutional ownership, insider holding, debt, and dividend policy.The researchers showed that dividend policy and the desire to seek external financing varies across firms, based on whether a firm is managerially controlled or shareholder controlled. As managers are self-seeking opportunities, they will finance growth with internally generated funds, to avoid submitting themselves to the evaluation of the capital market. This implies firms with higher insider holding will have lower levels of debt, as well as lower levels of dividend payout ratio. Shareholder-controlled firm will prefer higher levels of debt and dividend, so that managers have to subject 
themselves to market discipline and /or commit themselves to payout operating cash flow \{Jensen, 1986\}.

(Douglas, Cook, \& Jeon, 2006) investigated Korean firms in order to provide new evidence on the relationship between the ownership structure and payout policy in an emerging market. Authors found that foreign investors were are more attracted to dividend-paying firms.

Among dividend-paying firms, however, foreign investors prefer low dividend-paying firms. They found that a higher level of stock repurchases attract more foreign investors. Thus, foreign investors are more active

Monitors of corporate by reducing agency problems and leading firms to increase the level of payouts. In general, foreign investors prefer larger and highly profitable firms.

In case of Jordan, (Al-Malkawi, 2005) showed that the degree of ownership dispersion was not found to affect the level of dividends or the decision to pay dividends. On the other hand he showed that the proportion of total shares held by insiders has a negative impact on the level of dividends paid but not in the decision to pay dividends, and the agency costs play role in determining the size of dividends. Similarly, the existence of government or its agencies in a firm's ownership structure (controlling-shareholders) was found to affect the size of dividends positively but not likelihood to pay dividends.He also he found that a firm's financial leverage is significantly and negatively related to its dividend policy.

\section{Previous Studies}

Here listed are related studies to the present field of study, classified by dates, and the search for further studies is ongoing.

(Khan, 2006). Company dividends and Ownership structure Evidence from UK Panel Data

This study investigated the relationship between dividends and ownership structure for a panel of 330 large listed UK firms. A result indicated a negative relationship between dividends and ownership concentration. Ownership composition also matters, with a positive relationship observed for shareholding by insurance companies, and a negative one for poor individual.These results are consistent with agency models in which dividends substitute for poor monitoring by a firm's shareholders, but can also be explained by the presence of powerful principle which is able to impose their preferred payout policy upon firms. The econometric model of this study as follow

$$
\text { Dit }=\alpha+\beta \Pi i t+\gamma \text { Sit }+\varphi \text { Levit }+\theta \text { Oit }+ \text { uit }
$$

Where Dit is the level of gross dividend paid by firm $\mathbf{I}$ in period $\mathbf{t}$. Mit

Is net profit, Sit is sales, Levit is financial leverage. Oit is the relevant ownership variable, uit error term.

(Mancineelli \& Ozkan, 2006). Ownership Structure and Dividend Policy Evidence from Italian Firms 


\section{MlMacrothink}

Journal of Management Research

ISSN 1941-899X

2013, Vol. 5, No. 2

The study investigated the relationship between the voting rights of large shareholders and the firm dividends policy tests have been carried out with the view that the dividend policy of firms may be used to expropriate wealth from minority shareholders by large shareholders.A sample of 139 Italian listed corporations have been considered. The TOBIT regression results suggest a significantly negative impact of the voting rights of the largest shareholder on the firm's dividend payout. According to these results, the monitoring power of 'strong' large shareholders except the largest is very limited.To some extent, this finding might be explained by the impact of agreements among shareholders on the firm dividend policy. In fact, they found support for the hypothesis that the presence of voting syndicates has some impact on the dividend policy.That is, when block- holder s are held together by a coalition of the dividend payout is higher.This last finding is also supported by the LOGIT model analysis when the dependent variable is a dummy representing the decision to pay or not to pay dividends.The results obtained when the degree of separation between ownership and control is included among the regression as an additional measure of a firm's vulnerability to insider expropriation, does not allow us to reject the hypothesis that investor might perceive the risk of expropriation and thus may be less willing to supply resources to corporates that pursue a low level dividends policy.

(Wallgern, 2006). Dividend policy and ownership structure in Swedish firms.

The data set of this study covered 266 listed companies and 24306 non- listed companies in 2002 of Swedish firms. The study employed the ordinary least squares (OLS) regression and logistic regression to test hypotheses.It study investigated if ownership structure is linked to the dividend policy in Swedish firms, and found that the leverage is not related to dividend levels and propensity to pay dividend.The votes of the largest shareholder are not related to dividend levels but significantly positively related to the propensity to pay dividend. The type of the controlling shareholder (families, corporation, and institutions) does not seem to have a significant effect on dividend levels.

(Douglas, \& Jin,2006) Foreign Ownership, Domestic Ownership, and Payout Policy. They extended the U.S literature between institutional ownership and payout policy was using the unique features of foreign ownership in Korea. They investigated Korean firms in order to provided new evidence on the relationship between the ownership structure and payout policy in an emerging market.

They found that foreign investors are more attracted to dividend-paying firms. Among dividend-paying firms, however, foreign investors prefer low dividend-paying firms. They also found that a higher level of stock repurchases attract more foreign investors.

In support of the agency model, higher foreign ownership is associated with a greater dividend payout. Domestic institutional investors, however, do not play a prominent role in a firm's payout policy. Thus, they a concluded that foreign investors are more active monitors of corporate by reducing agency problems and leading firms to increase the level of payouts. In general, foreign investors prefer larger and highly profitable firms. 
(AL-Malkawi, 2005). Dividend policy of publicly quoted companies in emerging markets the case of Jordan

This study examined the determinants of dividend policy of publicly quoted companies in Jordan as a case study of an emerging market.The sample of this study consisted of 160 companies quoted in (ASE) of which 75 are industrial companies, 43 service companies, 26 insurance companies and 16 banks, during 12 years from 1989-2000.In this study the researcher, have used the analysis based on a panel data set constructed from the available data and he used Tobet and probet estimation to examine the determinants of the amount or the level of dividends paid by the firms and the decision to pay dividends. The general model of this study as follow.

$\mathrm{DYLD}=\gamma 0+\gamma 1 \mathrm{STOCK}-\gamma 2 \mathrm{INSD}-\gamma 3 \mathrm{FAML}+\gamma 4 \mathrm{STAT}+\gamma 5 \mathrm{INST}+\gamma 6 \mathrm{MULT}+\gamma 7 \mathrm{AG}-$ $\gamma 8 \mathrm{AGESQ}-\gamma 9 \mathrm{MBR}-\gamma 10 \mathrm{DER}-\gamma 11 \mathrm{TURN}-\gamma 12 \mathrm{DTAX}+\gamma 13 \mathrm{MCAP}+\gamma 14 \mathrm{EPS} \pm \gamma 15 \mathrm{NONFIN}+\varepsilon$

Where:

DYLD $=$ is the dividend yield.

The researcher found that the ownership dispersion as measured by the natural log of the number of stockholders(STOCK), seems to have no relation to dividend policy.That means it has no effect either on the level of dividend or on the decisions to pay dividend.Insiders (INSD) have negative impact on the level of dividend paid but not on the decision to pay dividends.Similarly the existence of government or it agencies in a firm's ownership structures (controlling shareholders) effect the amount of dividend, (positively) but not the likelihood to pay dividend. Other variables of ownership structures seems to have no influence on dividend policy.The firm size and profitability are also found positively and significantly related to dividend policy. They also found that a firm's financial leverage is significantly and negatively related to dividend policy

(Farinha, 2005). The relation between dividends and insider Ownership in different legal system: international Evidence

The relation between dividends and insider ownership in different legal systems: International Evidence. The sample of this study contained 931 companies over the period 1996-2000, and involved a total of 4092 firms year observation. Of the total number of the companies, 462 were from US and 469 were European.

The study provided new international evidence on the relationship between dividend policy and insider ownership by analyzing a sample of firms from countries characterized by an Anglo-Saxon and matching sample of companies from countries with civil legal systems. He found the relation between dividends and insider ownership from Anglo-Saxon(Common Law) countries follows the negative-positive-negative pattern, where lower concentration of ownership and better minority rights protection determine agency problems which are fundamentally centered on the relation between managers and shareholders, the results for firms in these countries show a negative relation between insider ownership and dividend 
payout at ownership levels below $36 \%$ or above $95 \%$, and a positive one between those two critical levels. This is in accordance to a growing convergence of interest between management and shareholders when the concentration of ownership increases but is maintained at percentage below the $36 \%$ or above $95 \%$. In this situation dividends seem to lose their importance as a device for reducing agency problems arising between these two parties.On the other hand, for ownership levels between these two inflection points a positive relation is observed between both variables, which we interpret as a result of an entrenchment effects, causing dividend payments once again to become necessary to reduce this new type of agency problem.After the second critical insider ownership level (95\%), dividends are reduced once again, in accordance to an alignment of interest effects that is apparently stronger than any possible drive for liquidity on the part of majority shareholders.

In firms of Civil Law Countries the relation is positive -negative -positive. Given the low level of protection of minority shareholders in these countries, dividend payment increase as insider ownership more concentrated until a critical level of $46 \%$ ownership, possibly as a way of enticing external shareholders to invest in the company. A positive association between dividends and internal ownership becomes then observable when insider ownership rises above the level of $77 \%$, consistent with liquidity needs faced by majority shareholders when ownership is very concentrated. However, when insider shareholders exercise majority control over the firm, with levels of participation at around half of total shares, dividends are cut back which could well be explained by a strategy of assigning resources that is oriented more towards obtaining private benefits rather than the creation of value for all shareholders.

(Julie, Elston, \&Junsoo Lee, 2004). Dividend policy and Institutional ownership

This study investigated the relationship between institutional ownership and dividend payout behavior of the firms in Germany. The researchers used the propensity scoring method estimator to control endogenously problem. They find evidence that neither institutional ownership nor bank control is statistically significant in determining dividend payout.

These finding consistent with stylized facts regarding the nature of the German institutional environment, which through the right of the management to retain a significant percentage of the net profit of the firm and lack tax incentives, reduce agency costs associated with conflict between management and shareholders' interests regarding use of the firm free cash flow.

(kumar, 2004). Corporate Governance and dividend payout in India

This study offered an empirical examination of the agency theory explanation of the distribution of dividends policy in India, especially, analyzing the relationship between ownership structure, corporate governance, and dividend payout using a large panel of Indian corporate firms over 1994-2000.He found that the ownership was one of the important variable that influence the dividend payout policy. The relationship is different for different class of owners and at different level, ownership by the corporate and directors is positively related with dividends payout in level, and corporate ownership is negatively related in square.institutional ownership has inverse effect on dividends in comparison to corporate 
ownership in levels as well as in its square.He found no evidence in favor of association between foreign ownership and dividend payout growth.

(Gugle, 2003). Corporate governance, dividend payout policy, and the interrelation between dividends, R\&D and capital investment.

This study investigated the relationship between dividends, ownership and control structure of the firm, of the panel of Austrian firm over the 1991-1999 period. This study found that the ownership and control structure of the firm was significant determinant of its dividend payout policy.In particular, state-controlled firms in Austria "smooth" dividends, have large target payout ratio, and are most reluctant to cut dividends, despite of the potential cost involved for shareholders, this is consistent with a managerial /agency cost explanation. In contrast, family -controlled firms peruse a significantly different dividend policy. These firms show no smoothing in dividends, have lower target payout ratio, and are least reluctant to cut dividends. Owner-managers of these firms can be reactive to investment opportunities and financing needs, and adjust dividend policy accordingly.Smoothing of dividends is only marginally important in bank and foreign -controlled firms. Smooth and high dividend payouts are not necessarily optimal from bank perspective as this increase the risk of bankruptcy and reduce the security of interest payments. Banks have other means than dividends to reduce managerial agency costs, for example interest payments on dept

Ki, Suk Hun Lee \& David Y Suk,1999). Institutional shareholders and dividends.

This study examined the relationship between institutional ownership structure and corporate dividend policy. The data of the sample firms was collected from the Disclosure/spectrum Ownership Database, and on the CRSP NYES/AMEXS file. The database contained spectrum ownership information on over 5500 companies for the 1988-1992 periods. The final sample of this study consists of 303 firms. The Model of this study is:

$$
\begin{aligned}
& \mathrm{DYJT}=\dot{\alpha} 0+\dot{\alpha} 1 \mathrm{INTJT}+\dot{\alpha} 2 \mathrm{ISDJT}+\dot{\alpha} 3 \mathrm{GROJT}+\dot{\alpha} 4 \mathrm{CXAJT}+\dot{\alpha} 5 \mathrm{DTAJT}+\dot{\alpha} 6 \mathrm{SDRJT}+ \\
& \dot{\alpha} 7 \mathrm{OIAJT}+\alpha \dot{\alpha T D Y J T}+\dot{\mathrm{eJT}}
\end{aligned}
$$

\section{Where:}

DYJT = dividend yield for firm $\mathrm{j}$, period $\mathrm{t}$;

INTJT =institutional ownership in percentage for firm $\mathrm{j}$, period $\mathrm{t}$;

ISDJT = insider ownership in percentage for firm $\mathrm{j}$, period $\mathrm{t}$;

GROJT $=$ firm $\mathrm{j}$, s geometric average of revenue growth during the five year period $\mathrm{t}$;

CXAJT $=$ firm j, s capital expenditure on plant and equipment as a percentage of assets for period t;

DTAJT $=$ the ratio of debt to assets for firm $\mathrm{j}$ period $\mathrm{t}$;

SDRJT $=$ firm $\mathrm{j}$, s standard deviation of return on assets during the five year period $\mathrm{t}$;

OIAJT = operating income to assets for firm $\mathrm{j}$ period $\mathrm{t}$; 
TDYJT $=$ target dividend yield for firm $\mathrm{j}$ period $\mathrm{t}$;

$\dot{\mathbf{e}} \mathbf{J T}=$ error term.

In this study dependent of the agency-cost-hypotheses predicted that dividend payout is inversely related the degree of institutional ownership by contrast, under the tax-based hypothesis, dividends payout is predicted to be positively associated with institutional ownership, using the TOBIT regression they examine the relationship between institutional ownership and corporate dividend policy. Results showed that dividend payout was positively related to institutional ownership, thus supporting the tax-based hypotheses. This result suggested a certain type of "dividend clientele," that is institutions preference for dividends.

\section{Design and Methodology}

\section{Population of the study}

In March 1999, Amman Stock Exchange (ASE) was established and began operation as a non-profit, private institution with financial autonomy and administrative. It to run by a Chief Executive Officer (CEO) and seven number of board of directors drown from the private sector. ASE is considered as an extension to Amman Financial Market (AFM), which was established in 1978 in fulfilling (AFM) Law No.(31) 1976.

The ASE consists of four main sectors: Industrial, Banking, Services, and Insurance, where the financial sector ranked first, industrial second, service third and finally insurance sector, as shown in Table (1).ASE deals in two Markets: Primary Market and Secondary Market

Table 1. Listed companies in ASE as of January 1, 2009

\begin{tabular}{lccccc}
\hline Sector & Industrial & Banks & & Insurance Services & Total \\
No. of listed & 75 & 16 & 27 & 154 & 272 \\
Companies & & & & & \\
Percentage to the & & & & & \\
Total number & $27 \%$ & $.06 \%$ & $.1 \%$ & $57 \%$ & $100 \%$ \\
\hline
\end{tabular}

Sources of data:securities depository center ASE (2009

\section{Sample of the study}

The data set includes all industrial companies listed in Amman Stock Exchange (ASE) during 2000 to 2006. This period was selected due to that the annual ownership data on the Jordanian firms, are available until 2006. The ownership data set includes not only portfolio 
composition of all investors on the stock exchange, but also investors information such as the type of the investor (e.g. financial institutional vs. individual vs. foreign investor). The data set enables obtain precise information on the largest holdings of the firms, and the ownership structure breakdown by investor type for each firm listed on the ASE at the end of each calendar year. However, the period selected is fit for conducting this type of dividend study

\section{Primary Data of the Study}

The study database was obtained from three sources: Amman Stock Exchange, Securities Depository Center, and companies guide as a secondary data, elaborated as follows.

1. The data was collected from the annual report publications of public shareholding firms held by ASE. This data consists of balance sheet, cash flow statement, income statement, financial ratios, and other relevant information related to ownership structures. The analysis was based on annual data, because the data set annually (Fama and Babick, 1968), (Khan, 2006, Luciana \& Ozkan).

2. Another secondary data from website, books and articles

\section{Data and Key Variables of this study}

This study investigated the relationship between ownership structure and dividend policy.It consisted of the following variable.

Dependent variable: the dependent variable of this study is Dividend yield is defined as the dividend per share (DPS) divided by the closing market price per share (MPS) DYLD= DPS/MPS.

Independent variables: the independent variables of this study are As follows.

Leverage Ratio (LR): Which measures the ability of firms to meet their long-term payment requirements. This is a proxy of long-term financial distress, defined as the ratio of total liabilities to total asset at year-end $=$ Total Liabilities x100/ Total Asset.

profitability (ROA): ratio of profit before Depreciation, interest and tax (PBDIT) to total asset $=$ Net Income x100/Total Asset.

Firm Size: the natural logarithm of sales $= \pm \operatorname{Ln}(\mathrm{SA})$.

Family. Dummy variable equals one if an individual is the controlling shareholder and zero otherwise.

Multi. Dummy variable equals one if a firms is controlled by more than ownership, zero otherwise.

Institution. Dummy variable equals one if institution (include banks, insurance companies, pension funds, mutual funds and other financial institutions) is controlling the shareholder, zero otherwise.

Stock.the natural logarithm of the number of common stockholders of a firm measure of ownership dispersion. 
Insider. The percentage of a firm stock held by general manager or directors.

Foreigner: the percentage of shares held by foreigners

\subsubsection{Study model}

The study model is shown as: Independent variable dependent variable

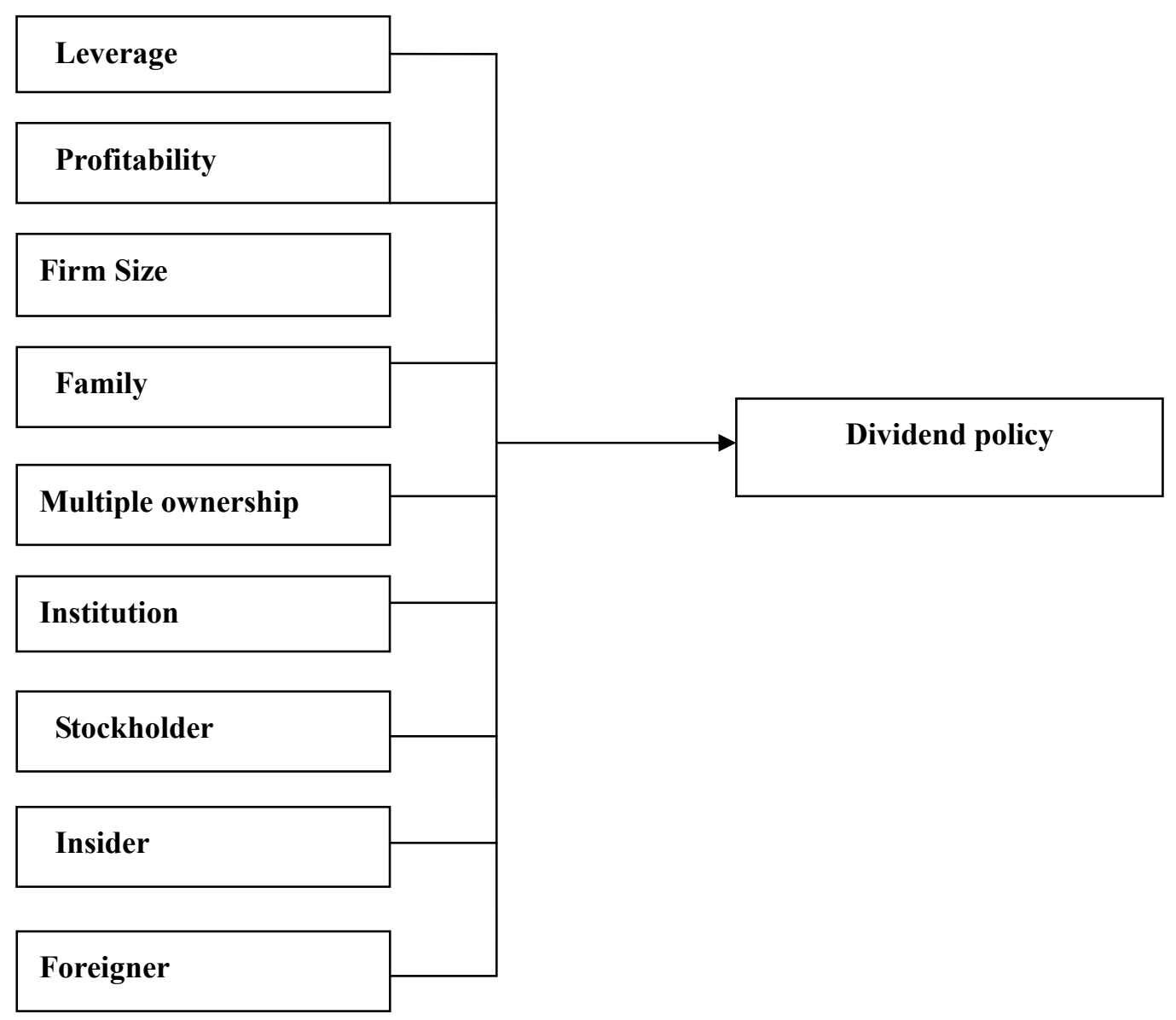

\section{Research Methodology}

\section{Statistical Analysis}

This research will make a methodological and an empirical contribution. It will depend on Tobit analysis model as will as(Eviews) software.

In considering the dividend decision firms have only two options, to pay or not to pay dividends.In the case of Jordan, many companies do not pay dividend at all, and even those who pay dividend do not pay them continuously and the dividend distribution is censored from below at zero. Therefore OLS estimates of coefficients might be inconsistent and biased towards zero. 


\section{Panel data analysis:}

The preceding subsection discusses cross sectional analysis for each year in the sample period, from 2000 to 2006 . The cross sectional data is stacked to form the panel data and the Tobit analysis, (Amemiya,1985), (Jorge Farinha, \& Oscar Lopeze, 2005),(KI C, Suk Hun Lee \& David Y Suk, 1999), used to test the relationship between dividend policy and ownership structure.

The estimated equation for linear regression model is:

$$
\begin{gathered}
\operatorname{DYLD}_{\mathrm{JT}}=\alpha+\beta 1 \mathrm{LEV}_{\mathrm{JT}}+\beta 2 \mathrm{ROA}_{\mathrm{JT}}+\beta 3 \mathrm{SIZE}_{\mathrm{JT}}+\beta 4 \mathrm{FAMI}_{\mathrm{JT}}+\beta 5 \mathrm{MULT}_{\mathrm{JT}}+\beta 6 \mathrm{INSTIT}_{\mathrm{JT}}+\beta 7 \mathrm{STOCK}_{\mathrm{JT}}+\beta 8 \mathrm{INSD}_{\mathrm{JT}}+\beta 9 \mathrm{FOREING}_{\mathrm{JT}}+\varepsilon j \mathrm{jt}
\end{gathered}
$$

Where is the:

$\boldsymbol{D} \boldsymbol{Y}_{\boldsymbol{J} \boldsymbol{t}}=$ dividend yield for firm j, period t;

$\boldsymbol{L E} \boldsymbol{V}_{\boldsymbol{J}}=$ the ratio of debt to asset for firm j, period $\mathrm{t}$;

$\boldsymbol{R} \boldsymbol{O} A_{J t}=$ the ratio of return to asset for firm, $\mathrm{j}$ period $\mathrm{t}$;

Firm SIZE $\mathbf{J t}_{\mathbf{J t}}=$ natural logarithm of sales for firm $\mathrm{j}$, period $\mathrm{t}$;

$\boldsymbol{F A M I} \boldsymbol{J t}_{\boldsymbol{t}}=$ dummy variable equals one if a firm $\mathrm{j}$ is controlled by an individual who is the controlling shareholder, period $\mathrm{t}$ and zero otherwise ;

$\boldsymbol{M U L T} \boldsymbol{T}_{\boldsymbol{J}}=$ dummy variable equals one if a firms $\mathrm{j}$ controlled by more than one type of owners, period $\mathrm{t}$ and zero otherwise ;

INSTIT $_{J t}=$ dummy variable equals one if a firm $\mathrm{j}$ is controlled by an institution, period $\mathrm{t}$ and zero otherwise.

$\boldsymbol{S T O C K}_{\boldsymbol{J t}}=$ the natural logarithm of the number of common stockholders for firm $\mathrm{j}$, period t;

$\boldsymbol{I N S \boldsymbol { D } _ { \boldsymbol { J t } }}=$ insider ownership in percentage for firm $\mathrm{j}$, period $\mathrm{t}$;

$\boldsymbol{F O R E I N}_{\boldsymbol{J t}}=$ foreigner ownership percentage for firm j, period t.

$\boldsymbol{\varepsilon j t}=$ error term

$\boldsymbol{\beta} 0, \boldsymbol{\beta} 1, \boldsymbol{\beta} 2 \ldots \boldsymbol{\beta}$ 9: are the parameter to be estimated, Constants.

\section{Study Hypotheses}

\section{Hypothesis 1:}

$\mathbf{H O}_{1}$ : There is no statistical significant relationship between Leverage and dividend policy.

\section{Hypothesis 2:}

$\mathbf{H O}_{2}$ : There is no statistical significant relationship between profitability and dividend policy.

\section{Hypothesis 3:}

$\mathbf{H O}_{3}$ : There is no statistical significant relationship between firm size and dividend policy. 


\section{Hypothesis 4:}

$\mathbf{H O}_{4}$ : There is no statistical significant relationship between firms held by Family and dividend policy.

\section{Hypothesis 5:}

H05: There is no statistical significant relationship between firms held by multiple and dividend policy.

\section{Hypothesis 6:}

H0$_{6}$ : There is no statistical significant relationship between firms held by institution and dividend policy.

\section{Hypothesis 7:}

$\mathbf{H 0}_{7}$ : There is no statistical significant relationship between a fraction of shares held by stockholders and dividend policy.

\section{Hypothesis 8:}

H08: There is no statistical significant relationship between The Insider and dividend policy.

\section{Hypothesis 9:}

H09: There is no statistical significant relationship between The foreigner ownership and dividend policy.

\section{Findings and Discussion}

\section{Descriptive statistics}

Table 2 presents summary statistics of all variables used in the analysis. The table reports the mean, standard deviation, minimum, maximum, and the number of observations for each of the dependent and independent variables. 


\section{Macrothink}

Table 2. Descriptive statistics for the dependent and independent variables

\begin{tabular}{lcccccc}
\hline Variable & Mean & \multicolumn{1}{c}{ Minimum } & Maximum Std.Ddev & Obs & \\
DYEILD & 2.822181 & 0 & 73.5 & 5.349214 & 434 & \\
LEVE & 35.41016 & 0.31 & 246.5 & 30.5063 & 434 & \\
ROA & 1.958046 & -279.6 & 26.14 & 16.23437 & 434 \\
SALES & 6.716284 & 3.071145 & 9.205969 & 0.837661 & 434 \\
FAML & 0.454756 & 0 & 1 & 0.498527 & 434 & \\
MULTI & 0.50116 & 0 & 1 & 0.50058 & 434 & \\
INSTITU & 0.545244 & 0 & 1 & 0.498527 & 434 & \\
STOCK & 3.032517 & 0.778151 & 6.596769 & 0.739681 & 434 \\
INSIDE & 13.3827 & 0 & 85.84 & \multicolumn{2}{c}{19.67581} & 434 \\
FOREING & 13.95471 & 0 & 98.1 & \multicolumn{2}{c}{19.53238} & 434 \\
\hline
\end{tabular}

Table 3 provides summary statistics on the number of firm years observation of yes or no dividends over the period 2000-2006.It also Table 4 reports that, more than half (55) of the firm observation in our sample have zero dividends. The highest percentage of firm-years records zero dividends was in 2001, while the lowest recorded zero dividends was in 2004.

Table 3. Summary Statistics on dividend yield (Number of Firm-Year Observation, 2000-2006)

\begin{tabular}{lllll}
\hline Year & $\begin{array}{l}\text { Zero value } \\
\text { (frequency }\end{array}$ & $\begin{array}{l}\text { Percentage } \\
(\%)\end{array}$ & $\begin{array}{l}\text { Positive value } \\
\text { (frequency }\end{array}$ & $\begin{array}{l}\text { Percentage } \\
\text { (\%) }\end{array}$ \\
\hline 2000 & 36 & 58 & 26 & 42 \\
2001 & 37 & 59.6 & 25 & 40.4 \\
2002 & 32 & 51.6 & 30 & 48.4 \\
2003 & 32 & 51.6 & 30 & 48.4 \\
2004 & 30 & 48.3 & 32 & 51.1 \\
2005 & 36 & 58 & 26 & 42 \\
2006 & 36 & 58 & 26 & 42 \\
Over all samp & 239 & 55 & 195 & 45 \\
\hline
\end{tabular}

\section{Analysis of the Results}

Table 5 reports the results of Tobit analysis, estimates are calculated by a maximum likelihood estimation (MLE) based on a Newton-Raphson algorithm of equation (4). 


$$
\begin{gathered}
\text { DYLDJT }=\alpha+\beta 1 \text { LEVJT }+\beta 2 \text { ROAJT }+\beta 3 \text { SIZEJT }+ \\
\beta 4 \text { FAMIJT }+\beta 5 \text { MULTJT }+\beta 6 \text { INSTITJT }+\beta 7 \text { STOCKJT }+\beta 8 \text { INSDJT }+\beta \text { FOREIGNJT }+\varepsilon j t .
\end{gathered}
$$

The table (5) shows three models in which dividend policy is measured by the dividend yield (DYELD). The general model (model 1) includes nine variables and encompasses the entire model, with 434 firm-year observation.

Five variables are significant at 5 percent in general model but other variables insignificant. (Model 2) includes seven variables leverage and stock variables where dropped from this model. The results of this model indicates that all variables of significant at 5 percent except multi, family and foreigner. (Model 3) includes seven variables; from this model two variables where dropped leverage and multiple. The results of this model indicates that all variables in this model are significant at 5 percent except stock and foreign variable. The estimate of $\beta_{1}$ is negative and significant for each model. This result strongly suggests that dividend yield is negatively related to the leverage. The estimate of $\beta_{2}$ is positive and significant, which indicates that the firms with high profitable tend to pay dividend. On the other hand unprofitable firms tend to set lower dividend payout. $\beta_{3}$ positive and significant, which indicates that large size firms are more able to pay dividend. The estimates of $\beta_{4}$ is negative and insignificant for each model, which indicates that no relationship between dividend yield and firms are held by family.The estimates of $\beta_{5}$ is negative in all models but not significant. The estimates of $\beta_{6}$ is positive and significant, which supports the view that institutional investors prefer dividend income over capital gains. The estimates of $\beta_{7}$ is negative and not significant, which means the stockholders do not related with dividend yield based the agency-cost hypotheses. The estimates of $\beta_{8}$ is negative and more significantly, which indicates a strongly relationship between dividend yield and insiders. The estimates of $\beta_{9}$ is positive and insignificant, which indicates that foreigners investors prefer firms that pay more dividends.

In Table 6, shows the regression analysis by (OLS) estimates. Despite they are not reliable estimates, but they are needed to compare between Tobit results and OLS results.The results estimated by Tobit analysis are statistically more significant than the OLS results. 


\section{Macrothink}

Table 5. Dividend yield and ownership structure: Tobit analysis

Dependent variable $=$ DYELD

\begin{tabular}{|c|c|c|c|}
\hline Independent & Model & Model & Model \\
\hline \multirow[t]{3}{*}{ Variables } & (1) & (2) & (3) \\
\hline & Coefficient & Coefficient & Coefficient \\
\hline & Estimates & Estimates & Estimates \\
\hline \multirow[t]{2}{*}{ Constant } & $-26.47063^{* *}$ & $-21.5562 * *$ & -17.51964 \\
\hline & $(.000)$ & $(0.000)$ & $(0.000)$ \\
\hline \multirow[t]{2}{*}{ Leverage } & $-0.036218 * *$ & & \\
\hline & $(0.0432)$ & & \\
\hline \multirow[t]{2}{*}{ ROA } & $0.614490 * *$ & $0.664245 * *$ & $0.673372 * *$ \\
\hline & $(0.000)$ & $(0.000)$ & $(0.000)$ \\
\hline \multirow[t]{2}{*}{ Sales } & $3.571467 * *$ & $2.20295 * *$ & $2.631011^{* *}$ \\
\hline & $(.000)$ & $(0.002)$ & $(0.001)$ \\
\hline \multirow[t]{2}{*}{ Family } & -1.264017 & -0.955529 & $-4.886603 * *$ \\
\hline & $(0.5542)$ & $(0.653)$ & $(0.002)$ \\
\hline \multirow[t]{2}{*}{ Multi } & -1.333117 & -1.286945 & \\
\hline & $(0.4694)$ & $(0.479)$ & \\
\hline \multirow[t]{2}{*}{ Istitut } & $6.74695 * *$ & $6.720639 * *$ & $5.5639881^{* *}$ \\
\hline & $(0.009)$ & $(0.009)$ & $(0.009)$ \\
\hline \multirow[t]{2}{*}{ Stock } & -0.912715 & -0.848320 & \\
\hline & $(0.244)$ & $(0.272)$ & \\
\hline \multirow[t]{2}{*}{ Insider } & $-0.090966^{* *}$ & $-0.082419 * *$ & $-0.087058 * *$ \\
\hline & $(0.000)$ & $(0.002)$ & $(0.001)$ \\
\hline \multirow[t]{2}{*}{ Foreigners } & 0.047173 & 0.0415595 & 0.042934 \\
\hline & $(0.1245)$ & $(0.171)$ & $(0.160)$ \\
\hline N.Observation & 434 & 434 & \\
\hline
\end{tabular}

For the Tobit analysis, estimates are calculated by a maximum likelihood procedure based on a Newton -Raphson algorithm.

p.value are shown within parentheses below each beta value. stars ( $\left.*^{\circ} * * \cdot * * *\right)$ represents the level of significance at 10,5,1 precedent level respective 


\section{Macrothink}

Table 6. Dividend yield and ownership structure: OLS analysis

Dependent variable $=$ DYELD

\begin{tabular}{|c|c|c|c|}
\hline Independent & Model & Model & Model \\
\hline \multirow[t]{3}{*}{ Variables } & (1) & (2) & (3) \\
\hline & Coefficient & Coefficient & Coefficient \\
\hline & Estimates & Estimates & Estimates \\
\hline \multirow[t]{2}{*}{ Constant } & -3.679111 & -2.695086 & -2.688042 \\
\hline & $(0.154)$ & $(0.2921)$ & $(0.294)$ \\
\hline \multirow[t]{2}{*}{ Leverage } & $-0.02225 * *$ & & \\
\hline & $(0.009)$ & & \\
\hline \multirow[t]{2}{*}{ ROA } & $0.046896 * *$ & $0.055302 * *$ & $0.05207 * *$ \\
\hline & $(0.004)$ & $(0.000)$ & $(0.001)$ \\
\hline \multirow[t]{2}{*}{ Sales } & $1.048969 * *$ & $0.697892 * *$ & $0.742922 * *$ \\
\hline & $(0.006)$ & $(0.037)$ & $(0.044)$ \\
\hline \multirow[t]{2}{*}{ Family } & -0.836226 & -0.744843 & -0.659451 \\
\hline & $(0.486)$ & $(0.536)$ & $(0.583)$ \\
\hline \multirow[t]{2}{*}{ Multi } & -1.151191 & -0.946381 & \\
\hline & $(0.226)$ & $(0.312)$ & \\
\hline \multirow[t]{2}{*}{ Istitut } & $3.172155^{* *}$ & $3.217766 * *$ & $2.51582 * *$ \\
\hline & $(0.019)$ & $(0.018)$ & $(0.034)$ \\
\hline \multirow[t]{2}{*}{ Stock } & $-0.120079 * *$ & -0.138964 & \\
\hline & $(0.7475)$ & $(0.706)$ & \\
\hline \multirow[t]{2}{*}{ Insider } & $-0.032107 * *$ & $-0.031067 * *$ & $-0.032317 * *$ \\
\hline & $(0.011)$ & $(0.014)$ & $-0.032317 * *$ \\
\hline \multirow[t]{2}{*}{ Foreigners } & 0.014955 & 0.016394 & 0.016632 \\
\hline & $(0.297)$ & $(0.255)$ & $(0.294)$ \\
\hline N.Observation & 434 & 434 & 434 \\
\hline
\end{tabular}

The OLS estimates are calculated using the inverse sample matrix.

p.value are shown within parentheses below each beta value.stars $\left(*^{*} * *^{9} * * *\right)$ represents the level of significance at $10,5,1$ precedent level respectively

\section{Conclusion}

In light of the study objectives and in order to answer the research questions outlined at the beginning of this study, the research has reached the following as overall conclusions. 
1. The result shows a significant and negative relationship between leverage and dividend policy That means the firms with high ratio of debt tend not to pay dividends or pay fewer shears of dividends. These results obtained here provided support all previous study found the same results.

2. The result show a significant and positive relationship between profitability and dividend policy that means the firms with high degree of profitability it's more related with dividend policy.

3. The firm size is significant and positive relationship with dividend policy. This result indicates that firms with large size are more able to pay more dividends compared to small firms, because the large firms have a relatively easy access to capital markets, and hence funds availability is less concern.

4. The result shows a negative and statistically insignificant relationship between family ownership and dividend policy. This result indicates that large shareholder or firms owned by family tend not to reduce the dividends. My interpretation of this result is due to the legal protection in Jordanian laws and the role of bank to controlling the firms.

5. The multiple ownership has negative and insignificant relationship with dividend policy. This result consistent with (Al-Malkawi, 2005).

6. The institution ownership is positive and significant relationship with dividend policy. This result consistent with (Kic.Han, 1999) who found a positive relationship between dividend yield and institutional ownership. (Mannos, 2002) found the same result.

7. Stockholder ownership is negative and statistically insignificant.This result show that minority shareholders are not related with dividend.

8. Insider ownership, the result show that a negatively and significantly relationship with dividend. The negative relationship between insiders and dividend policy supports view that insiders may become entrenched and then attempt extract private benefits instead of paying cash dividends to other shareholders (Maury and Pajuste, 2002).

9. Foreign ownership, the result show that a positively relationship but insignificantly with dividend.

10. The low $\mathrm{R}^{2}$ value found in the regression analyses indicating that ownership structure may not be important factor in dividends in Jordanian firms.

\section{Recommendation for the managers of companies}

1. In order to attract the foreign investment and to protect these capitals the researcher recommends providing the needed transparency and disclosure for the securities market and supplying necessary information to investors.

2. In order to attract the capitals of minority shareholders who have a desire to invest in these companies conducting an investor and a public awareness campaign with regards to investment in your companies in general and awareness of investor rights in particular. 
3. To protect minority shareholders, Providing effective mechanisms and procedures for the timely resolution of investor and public complaints.

\section{References}

Aivazian, Varouj, Laurence Booth, \& Sean Cleary, (2003). Do Emerging Market Firms Follow Different Dividend Policies From U.S. Firms?, The Journal of Financial Research, 26, 371-387. http://dx.doi.org/10.1111/1475-6803.00064

Aivazian,Varouj. (2004). Laurence Booth, and Sean Cleary, Dividend Smoothing, Working Paper, (University of Toronto, Rotman).

AL-Malkawi Husam- ALdin. (2005). Dividend policy of publicly quoted companies in emerging markets the case of Jordan. School of Economic and Finance, University of Western Sydney.

Amemiya, Takeshi. (1985). Advanced Econometrics, Cambridge, Harvard University.

Brennan, Michael J., \& Anjan V. Thakor, (1990). Shareholder preference and dividend poli4cy. Journal of finance, XLV(4), 993-1018.

Derhaene. Ooghe H. (1998).board composition, corporate performance and dividend policy. work paper, University Gent, faculty of Economic

Douglas O. Cook, \& Jin Q. Jeon (2006). Foreign Ownership, Domestic Ownership, and Payout Policy, working paper, university of Alabama, department of economic.website

Easterbook, Frank H. (1984). Two Agency-cost explanation of dividends, American Economic Review, 74(4), 650-659.

Faccico, Marra, Lary H. P. Lang, \& Leslie young. (2001). dividends and Expropriation. American Economic Review, 91, 54- 78.

Fama, Eugene F., \& Kenneth R. French (2001). Disappearing Dividends: Changing Firm Characteristics or Lower Propensity to Pay? Journal of Financial Economics, 60, 3-43. http://dx.doi.org/10.1016/S0304-405X(01)00038-1

Farinha. J. ,\& Oskar Lopez (2005). The relation between dividends and insider Ownership in different legal system: international Evidence, Working paper.

Gugler, K. (2003). Corporate governance, dividend payout policy, and the interrelation between dividends /R\&D and capital investment. Journal of banking \&finance, 27, 1297-1321. http://dx.doi.org/10.1016/S0378-4266(02)00258-3

Gugler. K., \& B. Burcin Yutoglu. (2003). Corporate governance and dividend payout policy in Germany. Journal of banking \&finance, 47, 731-758.

Holderness,C. (2003). A survey of block holders and corporate control. Economic policy review, 9, 51-64. 
IM. Pandy. (2005). Financial Management ( $9^{\mathrm{TH}}$ Ed.), Publisher: Vikas Publishing House, EAN: 9788125916581

James S.ANG, Rebel.Cole, \& James Wuh Lin. (2000). Agency costs and ownership structure. The journal of finance, 14(1), 81-106.

Jensen, G.R., D.P. Solberg, \& T.S. Zorn (1992). Simultaneous Determination of insider ownership, debt, and dividend policies. Journal of Financial and Quantitative Analysis, 27, 247-263. http://dx.doi.org/10.2307/2331370

Jensen, Michael C. (1986). Agency Costs of Free Cash Flow, Corporate Finance, and Takeovers. American Economic Review, 76, 323-329.

Jensen, Michael C., \& William H. Meckling, (1976). Theory of the Firm: Managerial Behavior, Agency Costs and Ownership Structure. Journal of Financial Economics, 3, 305-360. http://dx.doi.org/10.1016/0304-405X(76)90026-X

Julie A. Elston R H., \& Junsoo L. (2004). "Dividend policy and Institutional ownership: Empirical Evidence using propensity score matching estimator. Paper provided by Max Planck Institute of Economics, Group for Entrepreneurship, Growth and Public Policy in its series Discussion Papers on Entrepreneurship, Growth and Public Policy with number -27.

Khan, T. (2006). Company dividends and Ownership structure Evidence from UK Panel Data. The Economic Journal, 116. http://dx.doi.org/10.1111/j.1468-0297.2006.01082.x

KIC. Han,Suk Hun Lee, \& David Y. Suk. (1999). Institutional Shareholders and dividends. Journal of finance and strategic decisions, 12(1).

Kumar, J. (2004). Corporate governance and dividends payout in India. working paper in the research conference on India's financial system.

La porta, R Lopez - de Silanes, \& Vishny, R. W. (2000). Agency problem and dividend policies around the world. Journal of finance, 55, 1-33.

La porta, R Lopez -de Silanes, Shilefier, A., \& Vishny, R. W. (1998). Law and finance. Journal of political Economy, 106, 1113-1155.

Linter,John. (1956). Distribution of incomes of corporations among dividends, retained earning and taxes. American Economic Review, 46, 97-113

Liu, S. Hu, Yahony. (2005). Empirical analysis of cash dividend payment in Chinese listed companies. Nature and science, 3(1).

Maddala. (2001). Advanced Introduction to Econometrics ( $3^{\mathrm{RD}}$ ed.), Publisher: Wiley; (May $8,2001)$.

Mancinelli, L., \& Ozkan, A. (2006). Ownership Structure and Dividend Policy Evidence from Italian Firms. The European journal of finance, 12(3), 265-282. 
Manos, Ronny. (2002). Dividend Policy and Agency Theory: Evidence on Indian Firms, Working Paper No. 41, (Institute for Development Policy and Management, University of Manchester).

Maury, C. Benjamin, \& Anete Pajuste. (2002). Controlling Shareholders, Agency Problems, and Dividend Policy in Finland. The Finnish Journal of Business Economics, 51, 15-45.

Meckling, William H. (1976).Theory of the firm: Managerial Behavior, Agency Costs and Ownership Structure. Journal of financial economic (JFE), 3(4).

Rozeff, Michael S. (1982). Growth, Beta and Agency Costs as Determinants of Dividend payout Ratios. The Journal of Financial Research, 5, 249-259.

Schooly, D.K., \& Barney. Jr (1994). Using dividend policy and managerial ownership to reduce agency cost. Journal of financial research, 17(3), 363-373.

Securities depository center ASE. (2009).

Shleifer \& Vishny. (1997). A survey of corporate governance. Journal of finance, 52, 737-782.

Shleifer, \& Vishny. (1986). large shareholders and corporate control. Journal of political economic, 94, 461-481.

Stiglitz.J.E. (1985). Credit market and the control of the capital. Journal of money credit and banking, 17. http://dx.doi.org/10.2307/1992329

Thomas Anderson. (2007). Econometrics, 121-123. Publisher: Cambridge University Press.

Wallgren, Anders. (2006). Dividend policy and ownership structure in Swedish firms. Master theses in finance, Stockholm School of economic.

Walter, James E. (1963). dividend policy its influence on the value of the enterprise. Journal of finance, 18, 281-291. 